JP LPPM UNRI, ISSN: 2086-4779, e-ISSN: 2715-8209

Jurnal Pendidikan

https://jp.ejournal.unri.ac.id/index.php/JP/index

\title{
IMPLEMENTASI METODE MIND MAPPING DALAM MENINGKATKAN MINAT DAN PRESTASI BELAJAR SISWA TERHADAP MATA PELAJARAN BAHASA INDONESIA DI SMA NEGERI 1 KOTO GASIB
}

\author{
Sumirah \\ SMA Negeri 1 Koto Gasib \\ sumirah19730918@gmail.com
}

\begin{abstract}
This study aims to determine the success of implementing the mind mapping method in increasing student interest and achievement in Indonesian subjects. The data collection technique of this research is observation, distributing questionnaires and daily tests. Observation data collection techniques using observation sheets about student learning interest and student completeness. The questionnaire distribution technique uses a questionnaire that will be filled in by students and the test technique uses a question sheet. The research method used is Classroom Action Research (PTK) with a research procedure of 2 cycles, each cycle for 3 meetings. The results of the study proved that students were very happy or enthusiastic about taking lessons using the mind mapping method. Students are also very active in following lessons. The teacher's appearance and the material presented are quite good, engaging and easy for students to accept. At the time of the test, all students seemed busy in doing the assignment and all students could complete the task well.

Keywords: mind mapping method, interest and learning achievement, Indonesian language lessons

Abstrak:. Penelitian ini bertujuan untuk mengetahui keberhasilan implementasi metode mind mapping dalam meningkatkan minat dan prestasi siswa terhadap mata pelajaran Bahasa Indonesia. Teknik pengumpulan data penelitian ini bersifat observasi, penyebaran angket dan tes/ulangan harian. Teknik pengumpulan data observasi menggunakan lembar observasi tentang minat belajar siswa dan kelengkapan siswa. Teknik penyebaran angket menggunakan angket yang akan diisi siswa dan teknik tes menggunakan lembar soal. Metode penelitian yang digunakan yaitu Penelitian Tindakan Kelas (PTK) dengan prosedur penelitiannya 2 siklus, masing-masing siklus untuk 3 kali pertemuan. Hasil penelitian membuktikan bahwa siswa sangat senang atau antusias dalam mengikuti pelajaran dengan metode mind mapping. Siswa juga sangat aktif dalam mengikuti pelajaran. Penampilan guru dan materi yang disajikan cukup baik, mengena dan mudah diterima siswa. Pada waktu ulangan, semua siswa terlihat asyik dalam mengerjakan tugas dan semua siswa dapat menyelesaikan tugas itu dengan baik.
\end{abstract}

Kata kunci: metode mind mapping, minat dan prestasi belajar, pelajaran bahasa indonesia 


\section{PENDAHULUAN}

Mata pelajaran Bahasa Indonesia mempunyai karakteristik yang berbeda dengan mata pelajaran lain. Perbedaan ini terletak pada fungsi bahasa sebagai alat komunikasi. Selain diperlukan penguasaan kosa kata dan tata bahasa, juga diperlukan keterampilan dalam mengaplikasikannya dalam kegiatan komunikasi, baik lisan maupun tulisan. Menulis merupakan salah satu keterampilan berbahasa yang mutlak harus dikuasai oleh siswa sekolah menengah atas (SMA). Pada keterampilan menulis, yang tujuan akhirnya adalah memproduk atau menghasilkan tulisan atau teks baik fungsional maupun monolog berdasarkan genre atau jenis teks, diharapkan siswa dapat memahami ciri-ciri dari suatu teks, dan dapat mengekspresikannya dengan kosa kata dan tata bahasa yang benar.

Di SMA Negeri 1 Koto Gasib banyak siswa khususnya kelas XI yang merasa kesulitan dalam mengikuti pelajaran Bahasa Indonesia khususnya pada materi pokok teks eksplanasi kompleks, struktur dan kaidah teks film/drama yang sudah ditentukan materinya kebanyakan siswa tidak segera melaksanakan, bahkan malah ditinggal ngobrol dengan materin di dekatnya. Nampak tidak serius dan malas mengerjakannya. Ada kemungkinan kesulitan itu dikarenakan bahwa selama ini, kebanyakan siswa menganggap mata pelajaran Bahasa Indonesia sebagai momok atau mata pelajaran yang sulit dan tidak menarik Akibatnya, siswa malas mengikuti pelajaran itu atau kurang serius dan malas mengerjakan tugas yang dibebankan oleh gurunya. Itu semua terjadi karena kurangnya motivasi dan kurang minatnya terhadap mata pelajaran Bahasa Indonesia. Ada siswa yang sudah mulai menulis, kemudian macet di tengah jalan, hal ini dikarenakan kesulitan memunculkan ide, padahal materi atau judul sudah ditentukan. Akibatnya tugas menulis banyak yang tidak dikumpulkan. Sudah dibuat PR pun, masih banyak yang tidak mengumpulkan. Sampai suatu saat, peneliti pernah memaksa, bahwa semua siswa harus mengumpulkan tugas menulis. Apa yang terjadi? Semua siswa benar-benar mengumpulkan tugas itu. Tapi setelah diperiksa, ternyata banyak pekerjaan siswa yang sama persis. Itu berarti banyak siswa yang tidak mengerjakan, melainkan hanya menyontek pekerjaan materinnya.

Nampaknya masalah yang dihadapi kebanyakan siswa kelas XI SMA Negeri 1 Koto Gasib pada pembelajaran aspek menulis ini cukup kompleks. Mulai dari kurangnya minat, kurangnya sarana, kurangnya motivasi sehingga kurang serius dalam mengikuti mata pelajaran Bahasa Indonesia 
sehingga berdampak pada lemahnya penguasaan tata bahasa yang sangat diperlukan dalam pembelajaran. Kalau melihat macetnya penulisan, itu berarti karena kurangnya pengorganisasian pokok pikiran. Idealnya, siswa harusnya memiliki minat belajar sehingga menghasilkan perubahanperubahan dalam bidang pengetahuan dan pemahaman, dalam bidang nilai, sikap dan keterampilan (winkel, 2009). Belajar dapat dikatakan berhasil jika terjadi perubahan dalam diri siswa, namun tidak semua perubahan perilaku dapat dikatakan belajar karena perubahan tingkah laku akibat belajar memiliki ciri-ciri perwujudan yang khas (Muhibbin, 2000).

Benar-benar memprihatinkan. Terlebih lagi, Bahasa Indonesia termasuk mata pelajaran yang di UN kan. Kalau tidak ada hal yang dapat menarik perhatian siswa dalam pembelajaran Bahasa Indonesia, entah itu metode, strategi, ataupun approach, nampaknya mereka akan semakin jauh atau benci dengan mata pelajaran Bahasa Indonesia yang pada gilirannya akan menurunkan kompetensi dan prestasi Bahasa Indonesia mereka. Seperti itulah gambaran betapa beratnya tugas guru Bahasa Indonesia menghadapi tantangan UN dan siswa yang seperti itu kondisinya.

Berdasarkan permasalahan-permasalahan tersebut di atas, peneliti mencoba menggunakan metode mind mapping untuk mengatasi sebagian dari permasalahan-permasalahan itu. Menurut Buzan (2013) mind mapping adalah salah satu cara mengajak individu untuk mengembangkan kegiatan berpikir ke segala arah, menangkap berbagai pikiran dalam berbagai sudut dengan signifikan dan mudah dipahami. Pembelajaran dengan metode mind mapping dapat mengarahkan suasana yang menyenangkan karena dalam proses pembelajarannya peserta didik dapat menuangkan ide-ide kreatifnya ke dalam konsep peta pikiran (Chafidho \& Marzuki, 2019). Dengan digunakannya metode ini diharapkan para siswa menjadi lebih tertarik untuk mengikuti mata pelajaran Bahasa Indonesia dan mempermudah penulisan maupun kompetensi menulis (Gustina, 2018; Kartini, 2018). Bagi siswa yang suka menggambar, dapat mengekspresikan gagasannya melalui gambar yang beraneka ragam dan warna dalam mind mappingnya. Kalau siswa sudah merasa tertarik, guru akan lebih mudah dalam menyampaikan materi kepada siswa yang harapannya siswa tidak lagi merasa kesulitan dalam mengikuti pelajaran Bahasa Indonesia khususnya pada kompetensi atau aspek menulis ini. 


\section{METODE PENELITIAN}

Penelitian ini merupakan pengembangan metode dan strategi pembelajaran. Metode dalam penelitian ini adalah metode penelitian tindakan kelas (Class Action Research) yaitu suatu penelitian yang dikembangkan bersama sama untuk peneliti dan decision maker tentang variable yang dimanipulasikan dan dapat digunakan untuk melakukan perbaikan. Alat pengumpul data yang dipakai dalam penelitian ini antara lain : catatan guru, catatan siswa, rekaman tape recorder, wawancara, angket dan berbagai dokumen yang terkait dengan siswa. Prosedur penelitian terdiri dari 4 tahap, yakni (1) perencanaan, (2) pelaksanaan, (3) pengamatan dan (4) refleksi. Refleksi dalam tahap siklus dan akan berulang kembali pada siklus-siklus berikutnya. Aspek yang diamati dalam setiap siklusnya adalah kegiatan atau minat belajar siswa saat mata pelajaran Bahasa Indonesia dengan metode Mind Mapping untuk melihat perubahan tingkah laku siswa, untuk mengetahui tingkat kemajuan belajarnya yang akan berpengaruh terhadap prestasi belajar dengan alat pengumpul data yang sudah disebutkan diatas. Data yang diambil adalah data kuantitatif dari hasil tes, nilai tugas serta data kualitatif yang menggambarkan minat belajar siswa, antusias siswa, partisipasi dan kerjasama dalam diskusi, kemampuan atau keberanian siswa dalam melaporkan hasil. Instrument yang dipakai berbentuk : soal tes, observasi, catatan lapangan. Data yang terkumpul dianalisis untuk mengukur indikator keberhasilan yang sudah dirumuskan. Waktu yang digunakan untuk penelitian ini selama 3 bulan mulai dari persiapan sampai dengan pelaksanaan penelitian. Prosedur penelitiannya 2 siklus, masing-masing siklus untuk 3 kali pertemuan.

\section{HASIL DAN PEMBAHASAN}

\section{Siklus I}

Pertemuan ke-1

\section{a. Perencanaan}

1. Menetapkan jadwal penelitian, pelaksanaan penelitian ini dijadwalkan bulan Januari s.d Maret 2019.

2. Menetapkan materi yang akan dilaksanakan pada saat penelitian, materi yang akan dibahas adalah tentang Teks eksplanasi kompleks, struktur dan kaidah teks film/drama.

3. Menetapkan kompetensi dasar yang akan dicapai adalah Memahami struktur dan kaidah teks eksplanasi kompleks, struktur dan kaidah teks film/drama baik melalui lisan maupun tulisan. 
4. Menyiapkan Rancangan Pelaksanaan Pembelajaran untuk 3 kali pertemuan, Rancangan Pelaksanaan Pembelajaran yang dimaksud adalah RPP yang disusun berdasarkan silabus dan bersifat penerapan di dalam kelas.

5. Bagi siswa dalam beberapa kelompok.

6. Menyusun Lembar Kegiatan Siswa berisi tentang tugas siswa untuk 3 kali pertemuan.

7. Menyiapkan peralatan (sumber belajar) seperti buku paket Bahasa Indonesia yang tersedia di perpustakaan sekolah dan buku-buku Bahasa Indonesia lainnya yang relevan.

8. Menyiapkan Instrumen evaluasi, dibuat berdasarkan prestasi belajar individu yang sudah ada dalam Rencana Pelaksanaan Pembelajaran.

\section{b. Pelaksanaan}

1. Mengecek kesiapan masing-masing siswa untuk mengikuti pembelajaran seperti: tersedianya buku paket Bahasa Indonesia, buku Bahasa Indonesia lainnya yang relavan (buku referensi), buku catatan dan buku latihan siswa.

2. Menyampaikan judul, tujuan pembelajaran, pentingnya materi pembelajaran dan menghubungkan dengan kehidupan siswa.

3. Guru mempersiapkan gambar-gambar sesuai dengan tujuan pembelajaran. Guru menempelkan gambar di papan tulis atau ditayangkan melalui LCD. Guru memberi petunjuk dan memberi kesempatan pada siswa untuk memperhatikan / menganalisa gambar.

4. Menginformasikan teknik jalannya pembelajaran dengan menggunakan metode mind mapping.

5. Menyampaikan materi/topik yang harus dikerjakan dan dikumpulkan oleh setiap siswa kepada guru.

6. Melakukan evaluasi (tes) untuk mendapatkan penilaian tentang penilaian proses selama tindakan berlangsung dan penilaian prestasi belajar tentang materi yang telah dipelajari.

7. Mengisi lembaran observasi. Kolaborator mengisi lembaran observasi selama proses pembelajaran berlangsung. 
8. Memberikan arahan untuk tugas berikutnya, guru selalu memberikan penjelasan tentang siklus pelaksanaan pembagian tugas atau hal-hal lain yang diragukan siswa dalam menyelesaikannya.

\section{c. Pengamatan}

Mengamati apakah guru sudah melakukan tindakan pembelajaran sesuai dengan rencana yang dibuat. Observasi juga bertujuan untuk melihat bagaimana minat belajar dan prestasi belajar siswa setelah siklus I dilakukan.

a) Minat Belajar Siswa

Tabel 1. Rekapitulasi data pengamatan minat belajar siswa pertemuan ke-1

\begin{tabular}{cccccc}
\hline \multirow{2}{*}{ NO } & MINAT BELAJAR SISWA & \multirow{2}{*}{ SISWA } & \multicolumn{3}{c}{ SCORE } \\
\cline { 5 - 6 } & & & A & B & C \\
\hline 1 & Memperhatikan Penjelasan Guru & 29 & 6 & 8 & 15 \\
\hline 2 & Terlibat Dalam Kegiatan Pembelajaran & 29 & 6 & 8 & 15 \\
\hline 3 & Mengajukan Pertanyaan & 29 & - & 12 & 17 \\
\hline 4 & Mengerjakan Tugas dengan Baik & 29 & - & 10 & 19 \\
\hline \multirow{2}{*}{} & Jumlah & 116 & 12 & 38 & 66 \\
\hline & Persentase & $100 \%$ & $10,34 \%$ & $32,76 \%$ & $56,89 \%$ \\
\hline
\end{tabular}

b) Tes prestasi belajar

Diberikan diakhir pertemuan untuk mengetahui sejauh mana kemampuan memahami Mind mapping dan implementasinya dalam Memahami struktur dan kaidah teks cerita pendek., yang diberikan secara individu kepada 29 siswa dan yang telah mencapai ketuntasan belajar baru 10 siswa dengan persentase 34,48\%, sedangkan sisanya siswa belum mencapai ketuntasan belajar dengan persentase $65,52 \%$.

c) Hasil Pengamatan

Berdasarkan hasil observasi dan penilaian pada pertemuan ke-1 maka hal-hal yang perlu mendapat peningkatan pada pertemuan berikutnya adalah :

1) Minat belajar

Skor A ( Sangat baik ) ada 10,34\% 
Skor B ( Baik ) ada 32,76\%

Skor C ( Cukup ) ada 56,89\%

2) Hasil tes

Dari hasil tes pada pertemuan ke-1 dari 29 siswa ada 10 anak yang belum mencapai KKM yang telah ditetapkan. Data hasil tes menunjukkan adanya 10 siswa yang belum mencapai KKM yaitu siswa yang bernomor urut : 2, 4, 5, 7, 12 15,17, 18,19, 20 Kepada 10 siswa tersebut akan dilakukan remedial. Kondisi tersebut di atas sebagai dasar untuk perencanaan peningkatan minat dan prestasi belajar siswa Kelas XI SMA Negeri 1 Koto Gasib pada pertemuan ke-2.

\section{Pertemuan ke-2}

\section{a. Perencanaan}

Berdasarkan hasil refleksi pada pertemuan ke-1 yang lalu maka perencanaan pada pertemuan ke-2 adalah sebagai berikut :

1. Mempersiapkan segala keperluan pada pertemuan ke-2 beserta perangkat pendukungnya

2. Memberikan tindakan lebih optimal hal-hal yang telah dipesankan dalam refleksi pertemuan ke-1

3. Pelaksanaan pembelajaran adalah dengan sistem pembelajaran di kelas rendah, yaitu pembelajaran Metode Mind Mapping, artinya seorang guru harus bisa mendorong siswa untuk aktif dalam menuangkan ide-idenya.

\section{b. Tindakan}

\section{a) Kegiatan Awal ( 15 menit )}

1. Setelah berdoa bersama guru mengecek kehadiran siswa

2. Memeriksa kesiapan siswa sesuai dengan materi yang akan dipelajari

3. Menginformasikan kembali hasil pembelajaran pada pertemuan ke-1

4. Mengajak siswa untuk lebih serius pada pertemuan ke-2

b) Kegiatan inti ( 40 menit )

1. Menginformasikan hal-hal yang harus ditingkatkan berdasarkan hasil refleksi pada pertemuan ke-1

2. Memberitahukan materi pada pertemuan ke-2 
3. Menginformasikan tujuan pembelajaran pada pertemuan ke-2

4. Siswa dibagi dalam kelompok kecil yaitu 6 kelompok dari 29 siswa

5. Penjelasan umum tentang materi pelajaran.

6. Meminta siswa untuk duduk sesuai dengan kelompoknya

7. Memantau dan mengingatkan siswa agar mengerjakan tugasnya lebih baik

8. Guru menunjuk kelompok tertentu untuk mempresentasikan hasil kerjanya di depan kelas

9. Memberi kesempatan kepada anggota kelompok lain untuk memberi tanggapan

10. Kegiatan dilakukan secara bergantian sehingga semua kelompok dapat menyampaikan hasil kerja kelompoknya

11. Memberi kesempatan bertanya kepada siswa tentang materi yang sedang dipelajarinya

12. Menyimpulkan hasil diskusi yang dikerjakan.

\section{c) Kegiatan akhir ( 15 menit )}

1. Penyampaian hasil evaluasi

2. Ulasan dan pemantapan

3. Di akhir pembelajaran, siswa diberi tugas rumah (PR), mencari teks lain yang berbentuk deskriptif.

\section{c. Observasi dan Penilaian}

a) Minat belajar

Berdasarkan pengamatan hasil minat belajar siswa adalah sebagai berikut:

Tabel 2. Rekapitulasi data pengamatan minat belajar siswa pertemuan ke-2

\begin{tabular}{|c|c|c|c|c|c|}
\hline \multirow{2}{*}{ NO } & \multirow{2}{*}{ AKTIVITAS } & \multirow{2}{*}{$\begin{array}{c}\Sigma \\
\text { SISWA }\end{array}$} & \multicolumn{3}{|c|}{ SCORE } \\
\hline & & & A & B & C \\
\hline 1 & Memperhatikan Penjelasan Guru & 29 & 5 & 10 & 14 \\
\hline \multirow[t]{2}{*}{2} & Terlibat & 29 & 5 & 10 & 14 \\
\hline & Pembelajaran & & & & \\
\hline 3 & Mengajukan Pertanyaan & 29 & 7 & 9 & 13 \\
\hline 4 & Mengerjakan Tugas dengan Baik & 29 & 6 & 10 & 13 \\
\hline & Jumlah & 116 & 23 & 39 & 54 \\
\hline
\end{tabular}




$\begin{array}{lllll}\text { Persentase } & 100 \% & 19,83 \% & 33,62 \% & 46,55 \%\end{array}$

b) Tes prestasi belajar

Diberikan diakhir pertemuan untuk mengetahui sejauh mana kemampuan membuat kalimatnya dikaitkan dengan materi "Hobby" yang dikuasai anak, yang diberikan secara individu kepada 29 siswa dan yang telah mencapai ketuntasan mencapai 13 siswa dengan persentase 44,83\%, sedangkan sisanya 16 siswa belum mencapai ketuntasan belajar dengan persentase $55,17 \%$.

c) Hasil Pengamatan

Berdasarkan hasil pengamatan dan penilaian pada pertemuan ke-2 maka hal-hal yang perlu mendapat peningkatan pada pertemuan berikutnya adalah :

1) Minat belajar

Skor A ( Amat baik ) ada 19,83\%

Skor B ( Baik ) ada 33,62\%

Skor C ( Cukup) ada $46,55 \%$

2) Data prestasi belajar yang menunjukkan ada 16 siswa yang belum mencapai KKM, yaitu siswa yang bernomor urut 2, 4, 5, 7, 9, 10, 12 15,17, 18,19, 20, 22, 24, 25, 26

Kepada 16 siswa ini akan dilakukan remedial. Kondisi yang ada di atas sebagai dasar untuk perencanaan peningkatan siswa Kelas XI SMA Negeri 1 Koto Gasib pada pertemuan ke-3.

\section{Pertemuan ke-3}

\section{a. Perencanaan}

Berdasarkan hasil refleksi pada pertemuan ke-2 yang lalu maka perencanaan pada pertemuan ke-3 adalah sebagai berikut :

1. Mempersiapkan segala keperluan pada pertemuan ke-3 termasuk berbagai perangkat pendukungnya.

2. Memberikan tindakan lebih optimal hal-hal yang telah dipesankan dalam refleksi pada pertemuan ke-2.

3. Pelaksanaan pembelajaran masih tetap dengan pembelajaran Metode Mind Mapping. 


\section{b. Tindakan}

\section{Kegiatan awal ( 15 menit )}

(1) Seteleh berdoa bersama, guru mengecek kehadiran siswa

(2) Memeriksa kesiapan siswa sesuai dengan materi yang akan dipelajari

(3) Menginformasikan hasil pembelajaran pada pertemuan ke-2

(4) Mengajak siswa untuk lebih bersungguh-sunguh dalam pertemuan ke-3

\section{Kegiatan inti ( 40 menit)}

(1) Menginformasikan hal-hal yang harus ditingkatkan berdasarkan hasil refleksi pada pertemuan ke-2

(2) Memberitahukan tentang materi yang akan dipelajari pada pertemuan ke-3 yaitu pembentukan kelompok untuk mengerjakan latihan soal yang mendukung pembuatan teks eksplanasi kompleks, struktur dan kaidah teks film/drama.

(3) Menginformasikan tujuan pembelajaran pada pertemuan ke-3

(4) Siswa dibagi dalam kelompok kecil yaitu 6 kelompok dari 29 siswa

(5) Penjelasan umum tentang teks eksplanasi yang diberikan pada pertemuan itu.

(6) Pemberian tugas kelompok

(7)Memantau dan mengingatkan siswa agar lebih agar mengerjakan tugasnya lebih baik

(8) Guru menunjuk kelompok tertentu untuk menentukan hasil dari tugasyang dikerjakan kelompoknya

(9) Memberi kesempatan kepada anggota kelompok lain untuk memberi tanggapan

(10)Kegiatan dilakukan secara bergantian sehingga semua kelompok dapat menyampaikan hasil kerja kelompoknya

(11)Memberi kesempatan bertanya kepada siswa tentang materi yang sedang dipelajarinya

\section{Kegiatan akhir ( 15 menit )}

(1) Penyampaian hasil evaluasi

(2) Ulasan dan pemantapan

(3) Pemberian PR

\section{c. Observasi dan Penilaian}

1. Minat belajar 
Tabel 3. Rekapitulasi data pengamatan minat belajar siswa pertemuan ke-3

\begin{tabular}{|c|c|c|c|c|c|}
\hline \multirow{2}{*}{ NO } & \multirow{2}{*}{ AKTIVITAS } & \multirow{2}{*}{$\Sigma$ SISWA } & \multicolumn{3}{|c|}{ SCORE } \\
\hline & & & A & B & C \\
\hline 1 & Memperhatikan Penjelasan Guru & 29 & 7 & 11 & 11 \\
\hline 2 & Terlibat Dalam Kegiatan Pembelajaran & 29 & 7 & 12 & 10 \\
\hline 3 & Mengajukan Pertanyaan & 29 & 7 & 12 & 10 \\
\hline 4 & Mengerjakan Tugas dengan Baik & 29 & 7 & 11 & 11 \\
\hline & Jumlah & 116 & 28 & 46 & 42 \\
\hline & Persentase & $100 \%$ & $24,14 \%$ & $39,65 \%$ & $36,21 \%$ \\
\hline
\end{tabular}

2. Tes prestasi belajar

Diakhir pertemuan untuk mengetahui sejauh mana kemampuan belajar Menulis yang dikuasai anak dari materi yang disampaikan, yang diberikan tugas secara individu kepada 29 siswa dan yang telah mencapai ketuntasan meningkat menjadi 17 siswa dengan persentase 58,62\%, sedangkan sisanya 12 siswa belum mencapai ketuntasan belajar dengan persentase $41,38 \%$.

3. Hasil Pengamatan

Berdasarkan hasil pengamatan dan penilaian pada pertemuan ke-3 maka hal-hal yang perlu mendapat peningkatan pada pertemuan berikutnya adalah :

a) Minat belajar

Skor A ( Amat baik) ada 24,14\%

Skor B ( Baik) ada 39,65\%

Skor C ( Cukup) ada 36,21

b) Data hasil tes menunjukkan ada 12 siswa yang belum mencapai KKM, yaitu siswa yang bernomor urut $2,5,7,9,11,14,16,17,19,20,21,23$. Kepada 12 siswa ini akan dilakukan remedial.

\section{d. Refleksi}

Kondisi yang ada di atas sebagai dasar untuk perencanaan peningkatan minat dan prestasi belajar siswa Kelas XI SMA Negeri 1 Koto Gasib pada pertemuan ke-4. Pembelajaran pada siklus I 
ini dilakukan agar siswa dapat memahami materi Teks eksplanasi kompleks, struktur dan kaidah teks film/drama dengan penerapan pembelajaran model Mind Mapping. Pada siklus I ini belum dilaksanakan secara optimal karena siswa belum terbiasa dengan metode ini sehingga aktivitas yang diharapkan belum maksimal. Aktivitas siswa dalam mengikuti pembelajaran masih bingung dengan metode pembelajaran yang dilaksanakan oleh guru karena siswa belum terbiasa menggunakan pembelajaran model Mind Mapping yang masih baru dan asing bagi mereka.

Berdasarkan uraian di atas maka tujuan yang ingin dicapai dari pembelajaran pada siklus I belum tercapai dan dari kegiatan pembelajaran perlu dianjurkan pada siklus berikutnya sedangkan aktivitas guru dalam mengelola kelas agar siswa aktif dalam kegiatan pembelajaran, membimbing diskusi kelompok, dan mengajarkan siswa untuk saling bekerjasama dalam kelompok masih perlu diingatkan lagi. Berdasarkan hasil dari siklus I ini maka selanjutnya pada siklus II rancangan pembelajaran harus dapat dilaksanakan dengan lebih menarik dan menyenangkan bagi siswa sehingga pembelajaran dapat berjalan dengan lancar. Guru berusaha menarik minat siswa untuk lebih aktif lagi dalam kelompok dengan memberi penjelasan bahwa semua yang aktif akan diberi nilai plus. Berdasarkan hasil refleksi pada siklus I, langkah selanjutnya pada siklus II adalah lebih mengaktifkan lagi siswa agar menjadi lebih aktif lagi dalam kegiatan pembelajaran dengan menciptakan suasana kelas yang kondusif, dan pada akhir pelajaran hendaknya guru memberikan kesimpulan atas pelajaran yang sudah diberikan. Kondisi yang ada di atas sebagai dasar untuk perencanaan peningkatan prestasi belajar Bahasa Indonesia siswa Kelas XI SMA Negeri 1 Koto Gasib pada pertemuan ke-4.

\section{Siklus II}

\section{Pertemuan ke-4}

\section{a. Perencanaan}

Berdasarkan hasil refleksi pada pertemuan ke-3 yang lalu maka perencanaan pada pertemuan ke-3 adalah sebagai berikut :

1. Mempersiapkan segala keperluan pada pertemuan ke-4 termasuk berbagai perangkat pendukungnya.

2. Memberikan tindakan lebih optimal hal-hal yang telah dipesankan dalam refleksi pada pertemuan ke-3 
3. Pelaksanaan pembelajaran masih tetap dengan pembelajaran Metode Mind Mapping yaitu berdasarkan kepada materi yang akan dipelajari.

\section{b. Tindakan}

\section{a) Kegiatan awal ( 15 menit )}

(1) Seteleh berdoa bersama, guru mengecek kehadiran siswa

(2) Memeriksa kesiapan siswa sesuai dengan materi yang akan dipelajari

(3) Menginformasikan hasil pembelajaran pada pertemuan ke-3

(4) Mengajak siswa untuk lebih bersungguh-sungguh dalam pertemuan ke-4

\section{b) Kegiatan inti ( 40 menit)}

(1) Menginformasikan hal-hal yang harus ditingkatkan berdasarkan hasil refleksi pada pertemuan ke-3

(2) Memberi tahukan tentang materi yang akan dipelajari

(3) Menginformasikan tujuan pembelajaran pada pertemuan ke-4

(4) Siswa dibagi dalam kelompok kecil yaitu 6 kelompok dari 29 siswa

(5) Penjelasan umum tentang Teks eksplanasi kompleks, struktur dan kaidah teks film/drama. Setelah dilaksanakan kegiatan awal pembelajaran seperti biasa, peneliti mengumumkan 9 siswa yang meraih nilai pretes tertinggi.

(6) Kesembilan siswa diminta maju kedepan dan satu persatu diminta memilih satu persatu materin yang akan dijadikan anggota kelompoknya.

(7) Memantau dan mengingatkan siswa agar lebih agar mengerjakan tugasnya lebih baik

(8) Guru menunjuk kelompok tertentu untuk menentukan hasil dari tugas yang dikerjakan kelompoknya

(9) Memberi kesempatan kepada anggota kelompok lain untuk memberi tanggapan

(10) Kegiatan dilakukan secara bergantian sehingga semua kelompok dapat menyampaikan hasil kerja kelompoknya

(11)Memberi kesempatan bertanya kepada siswa tentang materi yang sedang dipelajarinya

(12)Menyimpulkan hasil yang dikerjakan. 


\section{c) Kegiatan akhir ( 15 menit )}

(1) Penyampaian hasil evaluasi

(2) Ulasan dan pemantapan

(3) Pemberian PR

\section{c. Observasi dan Penilaian}

1. Minat belajar

Berdasarkan pengamatan rekapitulasi minat belajar siswa adalah sebagai berikut :

Tabel 4. Rekapitulasi data pengamatan minat belajar siswa pertemuan ke-4

\begin{tabular}{ccccccc}
\hline \multirow{2}{*}{ NO } & \multirow{2}{*}{ AKTIVITAS } & $\boldsymbol{\Sigma}$ & \multicolumn{3}{c}{ SCORE } \\
\cline { 5 - 7 } & & SISWA & A & B & C \\
\hline 1 & Memperhatikan Penjelasan Guru & 29 & 7 & 13 & 9 \\
\hline 2 & Terlibat Dalam Kegiatan Pembelajaran & 29 & 7 & 13 & 9 \\
\hline 3 & Mengajukan Pertanyaan & 29 & 7 & 13 & 9 \\
\hline 4 & Mengerjakan Tugas dengan Baik & 29 & 7 & 13 & 9 \\
\hline \multirow{2}{*}{} & & 116 & 28 & 52 & 36 \\
\hline & Jumlah & $100 \%$ & $24,14 \%$ & $44,83 \%$ & $31,03 \%$ \\
\hline
\end{tabular}

2) Tes prestasi belajar

Diberikan diakhir pertemuan untuk mengetahui sejauh mana kemampuan anak dalam memahami dan menguasai materi yang diberikan. Guru memberikan tugas secara individu kepada 29 siswa dan yang telah mencapai ketuntasan meningkat menjadi 21 siswa dengan persentase $72,41 \%$, sedangkan sisanya 8 siswa belum mencapai ketuntasan.

3) Hasil Pengamatan

Berdasarkan hasil pengamatan pada pertemuan ke-4 maka hal-hal yang perlu mendapat peningkatan pada pertemuan berikutnya adalah :

a) Minat belajar

Skor A ( Amat baik ) ada $24,14 \%$

Skor B (Baik) ada 44,83\%

Skor C ( Cukup) ada 31,03\% 
b) Data prestasi belajar yang menunjukkan ada 8 siswa yang belum mencapai KKM, yaitu siswa yang bernomor urut absen 5,7,9,1 2,14,20,24,26, 29 Kepada 8 siswa ini akan dilakukan remedial. Kondisi yang ada di atas sebagai dasar untuk perencanaan peningkatan prestasi belajar Menulis siswa Kelas XI SMA Negeri 1 Koto Gasib pada pertemuan ke-5.

\section{Pertemuan ke-5}

\section{a. Perencanaan}

Berdasarkan hasil refleksi pada pertemuan ke-4 yang lalu maka perencanaan pada pertemuan ke-5 adalah sebagai berikut :

a) Mempersiapkan segala keperluan pada pertemuan ke-5 termasuk berbagai perangkat pendukungnya.

b) Memberikan tindakan lebih optimal hal-hal yang telah dipesankan dalam refleksi pada pertemuan ke-4

c) Pelaksanaan pembelajaran masih tetap dengan pembelajaran Metode Mind Mapping yaitu berdasarkan materi yang akan dipelajari.

\section{b. Tindakan}

a) Kegiatan awal ( 15 menit )

(1) Seteleh berdoa bersama, guru mengecek kehadiran siswa

(2) Memeriksa kesiapan siswa sesuai dengan materi yang akan dipelajari

(3) Menginformasikan hasil pembelajaran pada pertemuan ke-4

(4) Mengajak siswa untuk lebih bersungguh-sunguh dalam pertemuan ke-5

b) Kegiatan inti ( 40 menit)

(1) Menginformasikan hal-hal yang harus ditingkatkan berdasarkan hasil refleksi pada pertemuan ke-4

(2) Memberi tahukan tentang materi yang akan dipelajari

(3) Menginformasikan tujuan pembelajaran pada pertemuan ke-5

(4) Siswa dibagi dalam kelompok kecil yaitu 6 kelompok dari 29 siswa

(5) Pada pertemuan ini dilaksanakan pembelajaran menulis dengan metode mind mapping. 
(6) Siswa dipersilahkan berkumpul dengan kelompoknya masing-masing untuk menulis deskripsi yang diawali dengan pembuatan mind mapping seperti yang baru dicontohkan. Pekerjaan yang selesai dikumpulkan dan yang belum (2 kelompok) dilanjutkan di rumah

(7) Memantau dan mengingatkan siswa agar lebih agar mengerjakan tugasnya lebih baik

(8) Guru menunjuk kelompok tertentu untuk menentukan hasil dari tugas yang diberikan

(9) Memberi kesempatan kepada anggota kelompok lain untuk member tanggapan

(10) Kegiatan dilakukan secara bergantian sehingga semua kelompok dapat menyampaikan hasil kerja kelompoknya

(11) Memberi kesempatan bertanya kepada siswa tentang materi yang sedang dipelajarinya

(12) Menyimpulkan hasil Tanya jawab (diskusi) yang dikerjakan.

c) Kegiatan akhir ( 15 menit )

1) Penyampaian hasil evaluasi

2) Ulasan dan pemantapan

3) Pemberian PR

\section{c. Observasi dan Penilaian}

a) Minat belajar

Berdasarkan pengamatan hasil minat belajar siswa adalah sebagai berikut:

Tabel 5. Rekapitulasi data pengamatan minat belajar siswa pertemuan ke-5

\begin{tabular}{llcccc}
\hline \multirow{2}{*}{ NO } & \multirow{2}{*}{ AKTIVITAS } & \multirow{2}{*}{ S SISWA } & \multicolumn{3}{c}{ SCORE } \\
\cline { 4 - 6 } & & A & B & C \\
\hline 1 & Memperhatikan Penjelasan Guru & 29 & 18 & 5 & 6 \\
\hline 2 & $\begin{array}{l}\text { Terlibat Dalam Kegiatan } \\
\text { Pembelajaran }\end{array}$ & 29 & 18 & 5 & 6 \\
\hline 3 & Mengajukan Pertanyaan & 29 & 18 & 5 & 6 \\
\hline 4 & Mengerjakan Tugas dengan Baik & 29 & 18 & 5 & 6 \\
\hline
\end{tabular}




\begin{tabular}{ccccc}
\hline Jumlah & 116 & 72 & 20 & 24 \\
\hline Persentase & $100 \%$ & $62,07 \%$ & $17,24 \%$ & $20,69 \%$ \\
\hline
\end{tabular}

b) Tes prestasi belajar

Diakhir pertemuan untuk mengetahui sejauh mana pemahaman siswa terhadap materi yang disampaikan, guru memberikan latihan secara individu kepada 29 siswa dan yang telah mencapai ketuntasan meningkat menjadi 24 siswa dengan persentase 82,76\%, sedangkan sisanya 5 siswa belum mencapai ketuntasan belajar dengan persentase $17,24 \%$.

c) Hasil Pengamatan

Berdasarkan hasil pengamatan pada pertemuan ke-5 maka hal-hal yang perlu mendapat peningkatan pada pertemuan berikutnya adalah :

a) Minat belajar

Skor A ( Amat baik ) ada 62,07\%

Skor B (Baik) ada $17,24 \%$

Skor C ( Cukup) ada 20,69\%

b) Tes Prestasi belajar

Data prestasi belajar yang menunjukkan ada 5 siswa yang belum mencapai KKM, yaitu siswa yang bernomor urut 7, 12, 16, 20, 25. Kepada lima orang siswa ini akan dilakukan remedial. Kondisi yang ada di atas sebagai dasar untuk perencanaan peningkatan prestasi belajar Bahasa Indonesia siswa Kelas XI SMA Negeri 1 Koto Gasib pada pertemuan ke-6.

\section{Pertemuan ke-6}

\section{a. Perencanaan}

Berdasarkan hasil refleksi pada pertemuan ke-5 yang lalu maka perencanaan pada pertemuan ke-6 adalah sebagai berikut :

a) Mempersiapkan segala keperluan pada pertemuan ke-6 termasuk berbagai perangkat pendukungnya.

b) Memberikan tindakan lebih optimal hal-hal yang telah dipesankan dalam refleksi pada pertemuan ke-5 
c) Pelaksanaan pembelajaran masih tetap dengan pembelajaran Metode Mind Mapping yaitu berdasarkan kepada materi yang akan dipelajari.

\section{b. Tindakan}

a) Kegiatan awal ( 15 menit )

(1) Seteleh berdoa bersama, guru mengecek kehadiran siswa

(2) Memeriksa kesiapan siswa sesuai dengan materi yang akan dipelajari

(3) Menginformasikan hasil pembelajaran pada pertemuan ke-5

(4) Mengajak siswa untuk lebih bersungguh-sungguh dalam pertemuan ke-6

b) Kegiatan inti ( 40 menit)

(1) Menginformasikan hal-hal yang harus ditingkatkan berdasarkan hasil refleksi pada pertemuan ke-5

(2) Memberi tahukan tentang materi yang akan dipelajari Menginformasikan tujuan pembelajaran pada pertemuan ke-6

(3) Siswa dibagi dalam kelompok kecil yaitu 6 kelompok dari 29 siswa

(4) Penjelasan umum tentang materi Teks eksplanasi kompleks, struktur dan kaidah teks film/drama

(5) Pada pertemuan ini dibahas semua tugas kelompok yang dikerjakan pada pertemuan sebelumnya.

(6) Memantau dan mengingatkan siswa agar lebih agar mengerjakan tugasnya lebih baik

(7) Guru menunjuk kelompok tertentu untuk menentukan hasil dari tugas yang dikerjakan kelompoknya

(8) Memberi kesempatan kepada anggota kelompok lain untuk memberi tanggapan

(9) Kegiatan dilakukan secara bergantian sehingga semua kelompok dapat menyampaikan hasil kerja kelompoknya

(10) Memberi kesempatan bertanya kepada siswa tentang materi yang sedang dipelajarinya

(11) Menyimpulkan hasil diskusi yang dilakukan.

c) Kegiatan akhir ( 15 menit )

1) Penyampaian hasil evaluasi 
2) Ulasan dan pemantapan

3) Pemberian PR

\section{c. Observasi dan Penilaian}

a) Minat belajar

Berdasarkan pengamatan pada pertemuan ke-6 terjadi peningkatan yang sangat signifikan terhadap minat belajar siswa. Peningkatan minat belajar siswa dapat dilihat pada tabel rekapitulasi di bawah ini :

Tabel 6. Rekapitulasi data pengamatan minat belajar siswa pertemuan ke-6

\begin{tabular}{|c|c|c|c|c|c|}
\hline \multirow{2}{*}{ NO } & \multirow{2}{*}{ AKTIVITAS } & \multirow{2}{*}{$\sum$ SISWA } & \multicolumn{3}{|c|}{ SCORE } \\
\hline & & & A & B & C \\
\hline 1 & Memperhatikan Penjelasan Guru & 29 & 27 & 2 & - \\
\hline \multirow[t]{2}{*}{2} & Dalam Kegiatan & 29 & 27 & 2 & - \\
\hline & Pembelajaran & & & & \\
\hline 3 & Mengajukan Pertanyaan & 29 & 27 & 2 & - \\
\hline 4 & Mengerjakan Tugas dengan Baik & 29 & 27 & 2 & \\
\hline & Jumlah & 116 & 108 & 8 & - \\
\hline & Persentase & $100 \%$ & $93,1 \%$ & $6,9 \%$ & $0 \%$ \\
\hline
\end{tabular}

b) Tes prestasi belajar

Diakhir pertemuan untuk mengetahui sejauh mana pemahaman siswa terhadap materi yang disampaikan, guru memberikan latihan secara individu kepada 29 siswa dan semua siswa telah mencapai ketuntasan belajar dengan persentase $100 \%$

c) Hasil Pengamatan

Berdasarkan hasil pengamatan dan penilaian pada pertemuan ke-6 adalah :

a) Minat belajar

Skor A ( Amat baik ) ada 93,1\%

Skor B ( Baik) ada 6,9\%

Skor C ( Cukup) ada 0\%

b) Tes Prestasi belajar 
Data prestasi belajar yang menunjukkan bahwa semua siswa sudah mencapai KKM yang ditetapkan.

\section{d. Refleksi}

Pembelajaran pada siklus II ini difokuskan agar siswa dapat memahami materi. Aktivitas yang berkaitan dengan minat belajar siswa dan tes prestasi belajar pada siklus II ini telah menunjukkan kemajuan. Pada siklus II ini siswa menjadi lebih aktif dalam belajar, berusaha untuk meneliti dan menganalisa data, serta memecahkan masalah. Kerjasama siswa juga mengalami banyak peningkatan. Pada siklus II ini guru telah mampu mengelola kelas dengan baik sehingga dapat tercipta suasana kelas yang kondusif. Pada siklus II nilai rata-rata siswa mengalami peningkatan dibandingkan dengan siklus sebelumnya dan pada siklus II ini tidak terdapat hambatan yang berarti, tetapi hendaknya perlu ditingkatkan lagi pengajaran dengan menggunakan pembelajaran model Mind Mapping untuk ikut berpartipasi dalam KBM. Berdasarkan tindakan yang telah dilakukan maka dapat disimpulkan bahwa dengan pembelajaran model Mind Mapping dapat meningkatkan minat dan prestasi belajar siswa dalam proses pembelajaran.

\section{Pembahasan}

Melalui pengumpulan data selama 2 siklus dan 6 kali pertemuan maka terkumpul data seperti berikut ini :

Tabel 7. Rekapitulasi data hasil penelitian

\begin{tabular}{lcccccccc}
\hline \multicolumn{1}{c}{$\begin{array}{c}\text { SUMBER } \\
\text { DATA }\end{array}$} & NIL & S1/P1 & S1/P2 & S1/P3 & S2/P4 & S2/P5 & S2/P6 & KET \\
\hline Minat & A & $10,34 \%$ & $19,83 \%$ & $24,14 \%$ & $24,14 \%$ & $62,07 \%$ & $93,1 \%$ & \\
Belajar & B & $32,76 \%$ & $33,62 \%$ & $39,65 \%$ & $44,83 \%$ & $17,24 \%$ & $6,9 \%$ \\
Siswa & $\mathrm{C}$ & $56,89 \%$ & $46,55 \%$ & $36,21 \%$ & $31,03 \%$ & $20,69 \%$ & $0 \%$ \\
\hline Prestasi & KKM & $19<$ & $16<$ & $12<$ & $8<$ KKM & $5<$ KKM & $100 \%$ & \\
nelajar & 80 & KKM & KKM & KKM & & & KKM & \\
\hline
\end{tabular}

Berdasarkan pengumpulan data tersebut di atas maka dapat dibaca bahwa :

1) Siklus I pertemuan ke-1 dari minat belajar belajar dan prestasi belajar dasar perbandingan untuk pertemuan-pertemuan berikutnya. 
2) Siklus ke-1 pertemuan ke-2 diperoleh data :

- Minat belajar Belajar : Pada Skor A meningkat menjadi 19,83\% dari pertemuan sebelumnya yaitu $10,34 \%$

- Prestasi belajar meningkat hal ini dibuktikan dari penurunan jumlah anak yang belum mencapai KKM dari 19 anak menjadi 16 anak.

3) Siklus I pertemuan ke-3

- Minat belajar Belajar : Pada Skor A meningkat menjadi 24,14\% dari pertemuan sebelumnya yaitu $19,83 \%$

- Prestasi belajar meningkat hal ini dibuktikan dari penurunan jumlah anak yang belum mencapai KKM dari 16 anak menjadi 12 anak.

4) Siklus II pertemuan ke-4

- Minat belajar Belajar : Pada Skor B meningkat menjadi 44,83\% dari pertemuan sebelumnya yaitu $39,65 \%$.

- Prestasi belajar meningkat hal ini dibuktikan dari penurunan jumlah anak yang belum mencapai KKM dari 12 anak menjadi 8 anak.

5) Siklus II pertemuan ke-5

- Minat belajar Belajar : Pada Skor A meningkat menjadi 62,07\%.

- Prestasi belajar meningkat hal ini dibuktikan dari penurunan jumlah anak yang belum mencapai KKM dari 8 anak menjadi 5 anak.

6) Siklus II pertemuan ke-6

- Minat belajar Belajar : Meningkat menjadi 93,1\% dari sebelumnya yaitu $62,07 \%$ pada poin A.

- Prestasi belajar Meningkat hal ini dibuktikan dari anak yang mencapai KKM $100 \%$.

Secara umum dari tiap pertemuan mengalami kenaikan atau peningkatan prestasi belajar. Pada bab ini penulis akan mencoba menyajikan data hasil penelitian dan hasil analisis data yang diuraikan persiklus penelitian. Adapun jumlah siklus penelitian ini adalah 2 siklus. Hal ini disebakan peroleh data dari dua siklus penelitian telah memberikan gambaran yang cukup signifakan pencapaian tujuan penelitian. Artinya, data yang diperoleh siklus demi siklus menunjukkan pada peningkatan prestasi belajar siswa yang menjadi konsentrasi dalam penelitian ini. 


\section{KESIMPULAN}

Metode mind mapping sangat diperlukan dalam pembelajaran Bahasa Indonesia khususnya untuk materi teks eksplanasi kompleks, struktur dan kaidah teks film/drama . Dengan membuat kerangka karangan dalam bentuk mind mapping yang dapat digambari dan diwarnai sesuka hati, dapat memotivasi siswa untuk mengekspresikan gagasannya melalui gambar yang beraneka ragam dan warna. Mind mapping juga dapat memunculkan ide, sehingga mempermudah siswa dalam menulis /mengarang. Selain itu, mind mapping juga dapat memunculkan kreatifitas, yang terlihat dari hasil karya siswa kelas XI SMAN 1 Koto Gasib yang bagus-bagus dan menarik, diluar dugaan peneliti.

Implementasi metode mind mapping dalam penulisan teks eksplanasi kompleks, struktur dan kaidah teks film/drama benar-benar menarik minat siswa. Hal ini dibuktikan dengan catatan hasil pengamatan guru Bahasa Indonesia SMAN 1 Koto Gasib, yang memberi catatan bahwa siswa sangat senang atau antusias dalam mengikuti pelajaran dengan metode mind mapping. Siswa juga sangat aktif dalam mengikuti pelajaran. Penampilan guru dan materi yang disajikan cukup baik, mengena dan mudah diterima siswa. Pada waktu ulangan, semua siswa terlihat asyik dalam mengerjakan tugas dan semua siswa dapat menyelesaikan tugas itu dengan baik.

\section{DAFTAR PUSTAKA}

Buzan, T. (2013). Buku Pintar Mind Map. Jakarta: PT. Gramedia Pustaka Utama.

Chafidho, I., \& Marzuki, I. (2020). Implementasi Metode Mind Mapping Untuk Meningkatkan Hasil Belajar IPS Peserta Didik Kelas 5 SD Negeri Indro Kebomas Gresik. JTIEE (Journal Of Teaching In Elementary Education), 3(2), p.1-21.

Gustina, Novi. (2018). Implementasi Metode Mind Mapping dalam Pembelajaran Aspek Writing dapat Menarik Minat Siswa Terhadap Mata Pelajaran Bahasa Inggris pada Siswa Kelas IX.4 SMPN 1 Mempura Tahun Ajaran 2017/2018. Jurnal Ppkn \& Hukum, Vol.13, No.2, p.125134.

Kartini, Lale Andi Yanti. (2018). Implementasi Metode Mind Mapping Untuk Meningkatkan Kompetensi Writing di Kelas VII SMP. Jurnal Riset Teknologi dan Inovasi Pendidikan, Vol.1, No. 1, p.01-12.

Muhibbin, Syah. (2000). Psikologi Pendidikan Dengan Pendekatan Baru. Bandung: Remaja Rosdakarya

Winkel, W.S.(2009). Psikologi Pengajaran. Jakarta : Gramedia. 